\title{
LIBERTY OF CONSCIENCE, NATURAL RIGHT AND ESSENCE OF LIBERTY OF THINKING Lucian Ioan TARNU
}

\author{
The Police Inspectorate of Sibiu County, Romania \\ lucian_tarnu@yahoo.com
}

\begin{abstract}
Liberty of thinking is an absolute characteristic of human rights manifested in our society and it has both an individual dimension - meaning having opinions and beliefs - and a social and political dimension - if we think at their development.

Liberty of thinking, conscience and religion represent some of the basic components of a democratic society. This also occurs as the most important elements of the identity of a nation and it contributes significantly to its proper development.

Human conscience can not and should not be directed by administrative means, but it should always be the result of its liberty of thinking and revealing thoughts. As it is regulated at the constitutional level, liberty of conscience has a complex content. It is one of the oldest citizen liberties, one of tradition, which is known under either its proper name or various aspects, such as liberty of speech, liberty of association and liberty of press.
\end{abstract}

\section{Keywords: Liberty of Conscience, Natural Right, Liberty of Thinking}

\section{Aspects of liberty of conscience}

Conscience is the essence and human particularity that relates to nature, society, and also to its way of being and, normally, to the Supreme Being.

Liberty of conscience is one of the first liberties existing in the list of human rights, especially for the fact that liberty of religion as part of fundamental citizen liberties, had its own history, marked by intolerance, prejudice, pain and suffering [1].

Throughout history, there were formulated theories and legal statements, the role of law as civilizing and pacifying factor being absolutely undeniable. Liberty of conscience is part of the so-called natural human rights, that existed before being assigned in constitutional or some other kind regulations. Constantin Noica said that there is a unilateral contradiction between liberty and law, if we accept the idea of the derived character of law related to the values of liberty. Thus, law can not contradict human liberty, but the latter can contradict the former.

At its core, it is a natural right which allows man to speak in private or in public about a particular conception regarding the world around, to have or not to have a religion. Meanwhile, it expresses liberty of thinking, of having opinions, theoretical concepts and feelings which are expressed publicly or privately, without the fact that someone can alter or censor them. Liberty of conscience is a natural right, because man is distinguished from the other forms of life by its very existence of conscience, liberty of thinking or having feelings.

Liberty of conscience is an essential one, it rules the existence and content of other liberties, such as liberty of speech, liberty of press, liberty of association, as these are means of expressing thoughts, religion and opinions. 
As shown by Maurice Duverger, mind reading machine has not been invented yet and that is why liberty of thinking remains a liberty of expressing thoughts or a liberty of shaping thinking. Individual's mind remains inviolable [2].

Any constraint represents a violation of this natural and inalienable right, it is a mutilation of the human spirit [3].

Liberty of conscience involves moral and conscience responsibility for the expressed thoughts. Responsibility, in general, including the legal one, occurs only when thought or opinion are expressed, and they can harm both someone's dignity, honor and liberty of thinking and social and legal order.

\section{Legal protection of liberty of conscience}

Protection of thinking and conscience aims to ban any kind of indoctrination or imposing an ideology, which is specific to totalitarian regimes. The right to have personal and religious beliefs is general and should be understood in a broad sense. Therefore, any indoctrination, especially in schools, is prohibited because it is an intolerable prejudice against liberty of conscience.

Liberty of conscience is guaranteed and legally protected by the Romanian Constitution, more precisely, by the Article 29 which regulates the content and the name.

Thus, there are stipulated the following:

1. liberty of thinking, liberty of opinion and liberty of religion can not be restricted in any way. No one can be constrained to adopt an opinion or to adhere to a religion against his beliefs;

2. liberty of conscience is guaranteed; it must be manifested in spirit of tolerance and mutual respect;

3. religious cults are free and are organized in line with their own regulations, under the incidence of law;

4. within relationships between religions there are banned any forms, means, acts or actions of religious conflict;
5. religious cults are indipendentt from the State and theyare supported by State, including the facilitation of religious assistance in army, hospitals, prisons, shelters and orphanages;

6. according to their principles, parents or tutors have the right to ensure education of underage children who they are responsible of.

Analysing this text, we understand that liberty of conscience is citizen's opportunity of expressing, publicly or privately, their conception about the world around, of adhering or not to a religious cult, or of belonging or not to a religious denomination. It has a complex content as it incorporates more "liberties" that can be analyzed only together.

Romania's New Penal Code, the Article 381 , incriminates the infringement of law refering to "hindering the exercise of liberty of religion." This law punishes the hindering of the free exercise of ritual of a religious cult, which is organized according to the law. The law also punishes the fact that a person is obliged to attend a ritual of a religious cult or to perform any action related to the exercise of such a ritual. The punishment is also applicable if a person is constrained, by violence or threats, to meet a forbidden act by the religious cult which he belongs to and which is organized according to the law.

International legal basis of liberty of conscience stipulated in:

a. Universal Declaration of Human Rights, in which the art. 18 provides that: "Everyone has the right to liberty of thinking, conscience and religion".

His right includes liberty to change his religion or belief, to manifest, individually or collectively, religious beliefs, in both the public and private area, through preaching, practicing, worshiping and undergoing rites.

b. European Convention on Human

Rights, art. 9, states that: "Everyone has the right to liberty of thinking, conscience and religion ". 
The European Commission stated that the Article 9 protects what is called "the inner dimensions" of a person, meaning the ones referring to personal beliefs or acts closely related to the latter [4]. Every person has the unrestricted right to formulate and express their own philosophy of life, obviously respecting the liberties of others and in compliance with the legal provisions in this matter. These inner dimensions of a person develops and manifests itself in a particular and individual way, according to everyone's conception of life.

However, this article does not protect any social behavior based on certain beliefs [5]. However, this article does not make man find conscience reasons in order to be out of any obligations imposed by law.

Restrictions of this right are stipulated in the European Convention on Human Rights, art. 9, paragraph. 2, as follows: "The limitations provided by law are necessary in a democratic society to protect public order, health, moral, or the others' rights and liberties". In this respect, there is an interesting assignment in the International Covenant on Civil and Political Rights where the Article 18 assigns a person's right to liberty of thinking, conscience and religion.

c. The Charter of Fundamental Rights of the European Union, article 10, states: "Everyone has the right to liberty of thinking, conscience and religion. This right includes liberty of changing his religion or belief, and of manifesting them individually or collectively, in public or in private, by religious cult, education, practice and undergoing rites.

The right to object to something by conscience reasons is recognized in accordance with the national laws governing the exercise of this right".

\section{Liberty of conscience in European} jurisprudence

The importance of liberty of thinking, conscience and religion was underlined by the European judges as one of the bases of a democratic society.
One of the most discussed and disputed cases in the field [6] was the ban imposed to a primary public school teacher in Turkey to wear the Islam headscarf during her job. This ban was based on the idea that "wearing such an Islam headscarf does not fit with the message of tolerance, respect for each other and, especially with equality and non-discrimination that teachers must share with his students in a democracy"[7]. Closely related to this case, it is the one adopted by France regarding the wearing of the Islam headscarf in public. Since 1989, the State Council has decided that "the religious principle is against that public education sector employees have the right to manifest their religious beliefs at work place".

Also, it is considered that the ban imposed to Muslim women to wear headscarfs in photos for issuing national identity card or passport does not violate the Article 9 of the European Convention on Human Rights.

In the „Kokkinakis against Greece” case refering to Jehovah's Witness sentenced for prozeletism, the European Court has made a great legal clarification. The Court decided that the law convicting Greek prozeletism activities of Jehovah's Witnesses was not proportionate with the aim to protect the others' rights. The European Commission, deciding on an application in 1976, assigned the fact that a prisoner must not have access to a religious book containing a chapter about martial arts, fact that was justified to protect public order and the others ' rights. The Court mentioned that sentencing Kokkianakis alters his liberty "to manifest his religion or belief" [8].

In the ,Metropolitan Church of Bassarabia and others against Moldova in 2001" case, the European Court declared a violation of the Article 9, stating that the state, by failing to recognize the Metropolitan Church of Bassarabia, infringed its duty of neutrality and impartiality on the assessment of the legitimacy of religious beliefs and that the interference was not proportionate to the aims declared by the 
government, refering to "territorial integrity and defending social peace and tolerance among believers".

\section{About objectionm of conscience}

Objection of conscience is defined as ,the right of a person or a community to deliberately refuse to comply with their legal obligations on behal of higher requirements dictated by his own conscience." [9].

According to several decisions taken in this field, the European Court of Human Rights assigned that no right of objection of conscience is among the rights and liberties guaranteed by the Convention, that is why the Convention does not impose the states the obligation to recognize the legitimacy of objection of conscience.

Objection of conscience can manifest in various forms, but, in practice, it appears especially during military service. If a state allows objection of conscience, replacing military service with civilian one, interested people can not depict a violation of the Article 4, which prohibits forced and compulsory labor concerning the civilian service replacement.

No other domains recognized any right to objection of conscience. In the case of C. c. of the United Kingdom in 1983, the Commission stated that the general obligation to pay fees can not be infringed because of reasons of conscience.

\section{Conclusions}

Postulating that one of the bases of a democratic society is the liberty of conscience, of thinking, of opinion, and religion, the International Law, the
European Community Law and the Law of Modern States, assign completeness and inviolability of liberty of thinking.

Throughout history, great changes that societies have experienced, were possible through the concrete manifestation of liberty of thinking, of conscience and of expression.

Let us remember that our Savior Jesus Christ has revolutionized the world by words, transmitting the Christian faith, which was written later on.

Martin Luther, pastor and doctor in theology in the early sixteenth century, communicated to the world the Catholic faith that was to become the Reformed. The first manifestation of liberty of thinking was the Protestant attitude of Martin Luther, who in 1517, posted on the church door in the Wittenberg castle, the 95 theses by which he demanded the correct interpretation of the Bible, the elimination of corruption, the sale of indulgences, and the rejection of the Pope's authority and of any religious hierarchies. [10].

The fundamental idea that liberty of conscience is based on, is the spirit of tolerance and mutual respect, starting from the reality of existence and the manifestation of extremely diverse ideologies (political, social, economic, cultural), religious beliefs, opinions and trends, that human being is centered on.

We may conclude saying that human being acquired liberty of thinking and, much later, liberty of expression before liberty of movement.

\section{References}

[1] Muraru I., Tănăsescu E.S., Romanian Constitution, comment on articles, I C.H. Beck Publishing House, Bucharest, 2008, p 283.

[2] Duverger M., Droit public, p. 178.

[3] Muraru I., The Constitutional Protection of Liberty of Opinion, Lumina Lex Publishing House, Bucharest, 1999, p 32.

[4] Selejan-Gutan Bianca, European Protection of Human Rights, 2nd edition, C.H. Beck Publishing House, Bucharest, 2006, p 155.

[5] Examples of convictions protected by the art 9: pacifism, environment, vegetarianism, hunting conception etc. 
[6] The Leyla Sahin cause c. Turkey, decided by a Grand Chamber of the Court on the 10th of November 2005.

[7] Sudre Frederic, European Law and International Human Rights, translated by Raluca Bercea and collective, Polirom Publishing House, Iasi, 2006, p. 347.

[8] Summary by V Berger, Jurisprudence of CEDO, 1997, pp 401-404.

[9] Sudre Frederic, European Law and International Human Rights, translated by Raluca Bercea and collective, Polirom Publishing House, Iasi, 2006, p. 347.

[10] Luther Martin, pastor and doctor in theology, was the first Protestant reformer whose reforms led to the birth-Lutheran Evangelical Church. He has also been Professor of Bible at the prestigious University of Wittenberg.

\section{Books:}

\section{Bibliography}

Romanian Constitution, comments on articles, I Muraru, E S Tănăsescu, C.H. Beck Publising House, Bucharest, 2008.

Muraru I., The Constitutional Protection of Liberty of Opinion, Lumina Lex Publishing House, Bucharest, 1999.

Bârsan Corneliu, European Convention of Human Rights. Comment on article, vol I, C.H.Beck Publishing House, Bucharest, 2010.

Voicu Adriana Camelia, The Right of Fundamental Liberty, Universul Juridic Publishing House, Bucharest, 2014.

Selejan-Gutan Bianca, European Protection of Human Rights, 2nd edition, C.H. Beck Publishing House, Bucharest, 2006.

Berger V., Jurisprudence of the European Court of Human Rights, I.R.D.O., 1997, pp. 401-404;

Gaudin P., Great Religions, Orizonturi and Lider Publishing House, Bucharest, 1999.

Duverger M., Droit public, P.U.F., Paris, 1968, p. 178.

Sudre F., European Law and International Human Rights, PUF, Paris, 2003

Sudre F., European Law and International Human Rights, translated by Raluca Bercea and collective, Polirom Publishing House, Iasi, 2006.

Sudre F., European Convention of Human Rights, PUF, Paris, 1997.

\section{Legislation:}

Romanian Constitution.

New Penal Code of Romania.

Universal Declaration of Human Rights.

European Convention of Human Rights.

Charter of Fundamental Rights of the European Union.

\section{Jurisprudence:}

D.C.C. no.72/1995 (The Official Journal no.167/ the 31st of July, 1995).

Kokkianakis cause against Greece, 1993.

Cause of Metropolitan Church of Bassarabia against Moldova, 2001.

Leyla Sahin cause against Turkey, 2005. 